\title{
Comparative study of structural and ecophysiological features of lichens of different ecological groups in rocky forest commu- nities of northernmost boreal zone (Karelia, Russia)
}

\author{
Anzhella Valerjevna Sonina*, Vera Ivanovna Androsova, Anna Andreevna \\ Tsunskaya, Liliya Evgenjevna Suroeva
}

Petrozavodsk State University, Department of Botany and Plant Physiology, Lenin str. 33, Petrozavodsk 185910, Russia

\begin{abstract}
The anatomical (thickness of layers of fungal and algal symbionts) and ecophysiological parameters (the content of photosynthetic pigments) of two lichen species (Hypogymnia physodes and Umbilicaria hyperborea) from rocky forest communities of northernmost boreal zone (North-West of Russia) were studied. H. physodes is a lichen with foliose thallus morphology and circumpolar distribution which colonizes almost every substrate. $U$. hyperborea is strictly epilithic lichen with umbilicate type of thallus morphology and arcto-alpine distribution. Despite the fact that the photobiont in two species are closely related taxa (unicellular green algae of the genus Trebouxia) a high variability of photosynthetic pigments content in $H$. physodes thalli has been revealed, whereas in U. hyperborea, the mycobiotic showed high structural variability. It can be concluded that both mycobiont and photobiont contribute to their adaptation to environmental factors. In the present study it was obtained that the proportion of variation in anatomical structures and the content of photosynthetic pigments probably less depends on taxonomic position of photobiont and more determined by the plasticity of the individual components of the symbiotrophic organism.
\end{abstract}

Key words: Umbilicaria hyperborea, Hypogymnia physodes, photosynthetic pigments, chlorophyll, mycobiont, photobiont, anatomy, specific thallus mass

DOI: $10.5817 / \mathrm{CPR} 2018-2-15$

\section{Introduction}

Lichens are symbiotic organisms which represent the successful mechanism of evolutionary adaptation, in which the photobiont provides carbon for both bionts while mycobiont protects it from high solar irradiance and other external factors (Gadd
2011). Being the pioneer organisms in primary succession on the mineral substrates, lichens dominate about $6 \%$ of the Earth's surface. They are particularly well distributed in polar regions where they play an important role in biogeochemical cycles.

Received July 13, 2018, accepted December 4, 2018.

*Corresponding author: A. Sonina <angella_sonina@mail.ru>

Acknowledgements: We are grateful to reviewers for valuable corrections and recommendations, which have improved the quality of our work. The study was supported by the Ministry of Education and Science of the Russian Federation (project № 5.8740.2017/8.9). 
They promote organic matter accumulation over the surfaces as well as the early stages of soil formation (Nash 2008).

Lichens are actively used as model systems in astrobiological studies, studying the limits of eukaryotic symbiosis in a variety of critical environmental conditions (de Vera 2012, Meeßen et al. 2013). Therefore, studies of adaptive properties of the lichen associations are of current interest in science. According to Usmanov et al. (2001), adaptation is a set of morphological, physiological and biochemical primary adaptive responses, providing the possibility of species-specific survival of the organism under the action of vertical and horizontal biotic interactions, as well as unfavorable for this type of environmental conditions. Adaptation reflects, on the one hand, the stability of biological systems (in

\section{Material and methods}

\section{Lichen species}

The objects of the study were two lichen species Hypogymnia physodes (L.) Nyl. and Umbilicaria hyperborea (Ach.). $H$. physodes is one of the circumpolar widespread epiphytic lichen species belonging to the family Parmeliaceae Eschw. It is a foliose species with narrow lobes and plagiotropic type of growth which is attached to the substrate by the rhizins of the lower cortex layer. Upper surface of the dorsoventral thallus is glossy, grey and the lower surface is black. This species colonizes almost every substrate and it is known as mesophyte-hygrophyte, moderate photophile, acidophilic, toxitolerant species (Wirth et al. 2013). In coniferous forests of Karelia this lichen is an absolute dominant of the trunks of the main forest-forming tree species. A wide distribution of $H$. physodes allows to study it in a wide range of different habitat conditions in order to investigate the adaptive properties of this lichen. $U$. hyperborea belongs to Umbilicariaceae family. Umbilicariaceae Cheval. family is this case it is a lichen system) to environmental conditions, and on the other hand, the process of adaptation of living organisms to constantly changing environmental conditions. Lichens are well adapted to extreme environmental conditions, as evidenced by the increase in their species diversity in the Arctic zone [1]. The combination of adaptive properties of the fungus and high productivity of algae provides the symbiotrophic organism with new adaptive properties, which its components do not individually possess (Gielwanowska et Olech 2012).

The aim of present study is to analyze the morphological and ecophysiological parameters of lichen species of different ecological groups from northernmost boreal forests in Karelia (NW-Russia).

an isolated group of lichenized Ascomycetes with an uncertain systematic position (Davydov et Zhurbenko 2008). Most species thrive well on the rock surfaces, mainly in polar and mountain areas of Russia. $U$. hyperborea is a widespread species in the Arctic region (Davydov 2004). U. hyperborea is obligatory epilithic with umbilicate foliose dark brown or black thalli and is characterized by the presence of gomphus which attaches the thallus to the substrate. It does not have any vegetative propagules and mature thalli have gyre apothecia. The studied species are characterized by heteromeric anatomical structure of thallus.

The photobiont of both lichen species is a green unicellular alga of an undescribed Trebouxia: for H. physodes it is related to T. jamesii subsp. angustilobata and provisionally named as $T$. hypogymniae (Hauck et al. 2007), for U. hyperborea - T. jamesii (Jones et al. 2013) 


\section{Study area}

The field work was carried out in the territory of the Kostomuksha Nature Reserve $\left(64^{\circ} 19^{\prime}-64^{\circ} 35^{\prime} \mathrm{N}, 30^{\circ} 38^{\prime}-30^{\circ} 03^{\prime} \mathrm{E}\right.$, 49.276 ha) which is located in northernmost boreal zone. The area is located within the Baltic Shield, on the eastern slopes of the West Karelian Hills. The terrain is flat with low hills covered with forest and wetlands. In the reserve, $60 \%$ of area is covered by forests with Pinus sylvestris dominanting the stands $(85 \%$, Gromtsev 2009). A dominant feature of the reserve is Lake Kamennoye ("Stone Lake"), which makes up to $20 \%$ of the reserve area. There are also 250 small lakes, and $12 \%$ of the reserve is covered with marshlands.

The Kostomuksha Nature Reserve is located in the Atlantic-Arctic climatic region of the temperate zone. Characteristic features of the climate are mild winters, cool summers and high humidity with maximum values (86-92\%) from November to December (Dorshakova 2004). The average monthly air temperature is $-13.3^{\circ} \mathrm{C}$ in January and $+16.5^{\circ} \mathrm{C}$ in July. The duration of

\section{Sampling design}

Lichen thalli of $U$. hyperborea were selected in the places with a high abundance of the studied species (80-100\% coverage) on the stone surfaces (Table 1). We collected thalli of two age groups, which differed in size and morphological structure. The first group was characterized by thalli under $1 \mathrm{~cm}$ in diameter and the presence of young apothecia. The second group was represented by mature thalli having over $1 \mathrm{~cm}$ in diameter and the presence of true gyre apothecia. In this study, old thalli (deformed by physical factors) were not considered. Altogether, there were 6 sets of samples of lichen thalli collected (each set contained 10-20 thalli). The total sample size was 112 thalli. the frost-free period is $85-90$ days. The average annual rainfall is about $500 \mathrm{~mm}$. Winter lasts from 175 to 185 days, the depth of the snow cover reaches $70-80 \mathrm{~cm}$ [2].

A total of 4 sample plots $25 \times 25 \mathrm{~m}$ were established in rocky pine forest communities. A detailed geobotanical description of the studied community was made for each sample plot including trees (height, age, basal area, crown density etc.) and the ground cover characteristics (shrub and herb cover, mosses and lichen cover) (Table 1) (Jarmishko et Ljanguzova 2002). The time-since-disturbance of the studied forest communities was $90-150$ years and was evaluated based on the analysis of cores extracted with an increment borer from living pine trees damaged by fire in a radius of $50-100 \mathrm{~m}$ from the territory of the each sample plot. The time since the last fire was accounted as the difference between the current tree age and its age at the moment of cambium damage (Jarmishko et Ljanguzova 2002).

The samples of $H$. physodes were collected from the northern side of the pine trunks and were also divided into 2 groups. The first group was represented by young thalli, smaller than $2 \mathrm{~cm}$, with single soredia. The second group contained mature thalli, larger than $2 \mathrm{~cm}$, with a high degree of soredia cover over the thalli. All the collected thalli were sterile. The total set of collected sample had 152 individual thalli.

To study anatomical characteristics of thallus, standard methods of optical microscopy were used (see Sonina et Tsunskaya 2016). Anatomical features of thalli were studied using a light microscope (Axio Scope A1, Carl Zeiss, Germany). Totally, 
more than 1000 anatomical slices of thalli and 3500 measurements of cross sections were made.

Anatomical sections through the thalli of studied species were located in the middle part, excluding the marginal zone and the zone around the gomphus. Fungal layers were clearly distinguished in the anatomical structure (the upper cortex layer, the lower cortex, medulla, total thickness of the thallus) as well as the algal layer. During the preparation of the cross sections of $H$. physodes, lower cortex separates from the thallus, therefore lower cortex layer thickness was not measured.

Based on mass and area measurements, specific thallus mass (STM) was calculated for each individual as $\mathrm{STM}=\mathrm{DM} / \mathrm{A}$ $\left(\mathrm{mg} / \mathrm{cm}^{2}\right)(\mathrm{DM}-$ dry weight of thallus, $\mathrm{A}$ - thallus area) following Gauslaa et Coxson (2011). The air-dry mass of thallus was determined by weighing on a scale
(OHAUS Discovery DV215CD, Switzerland). The thallus area was measured by scanning and calculated by using the program "Autocard".

Determination of photosynthetic pigments concentration was done by ethanol extraction method. Optical density of the extracts was measured by a SF-2000 spectrophotometer (Spectr, Russia) at the absorption maxima in 665 and $649 \mathrm{~nm}$ for chlorophyll $a$ and $b$, and pigment contents calculated according to (Sapozhnikov et al. 1978, Lichtenthaler et Wellburn 1983, Maslova et Popova 1993). Determination of carotenoids exploited the absorption value at $470 \mathrm{~nm}$ with an adjustment for the shift of the absorption spectra. The concentration of carotenoids was calculated using the equations of Lichtenthaler et Wellburn (1983). The contents of photosynthetic pigments were as means using 3 biological and 9 analytical replicates.

\begin{tabular}{|c|c|c|c|c|c|c|c|c|c|c|c|}
\hline $\begin{array}{c}\text { № } \\
\text { sample } \\
\text { plots }\end{array}$ & GPS & \multicolumn{2}{c|}{$\begin{array}{c}\text { Time- } \\
\text { since- } \\
\text { disturbance } \\
\text { (years) }\end{array}$} & $\begin{array}{c}\text { Coverage (\%) } \\
\text { Herb- } \\
\text { shrub } \\
\text { layer }\end{array}$ & $\begin{array}{c}\text { Basal } \\
\text { moss- } \\
\text { lichen } \\
\text { ayer }\end{array}$ & $\begin{array}{c}\text { Crown } \\
\left(\mathrm{m}^{2} \text { ha }^{-1}\right)\end{array}$ & $\begin{array}{c}\text { Tensity, } \\
\text { (\%) }\end{array}$ & $\begin{array}{c}\text { Age of } \\
\text { stand } \\
\text { pine } \\
\text { trees, } \\
\text { years }\end{array}$ & $\begin{array}{c}\text { Hcp, } \\
(\mathrm{m})\end{array}$ & $\begin{array}{c}\text { Dcp, } \\
(\mathrm{cm})\end{array}$ \\
\hline 1 & $\begin{array}{c}64^{\circ} 50^{\prime}- \\
34^{\circ} 23^{\prime}\end{array}$ & 90 & 76 & 24 & 26.0 & 51 & $100 \mathrm{P}$ & $91-119$ & 16 & 28 \\
\hline 2 & $\begin{array}{c}64^{\circ} 33^{\prime}- \\
30^{\circ} 20^{\prime}\end{array}$ & 140 & 85 & 42 & 31.7 & 57 & $\begin{array}{c}87 \mathrm{P} \\
28 \mathrm{~S} \\
5 \mathrm{~B}\end{array}$ & $75-297$ & 16 & 29 \\
\hline 3 & $\begin{array}{c}64^{\circ} 33^{\prime}- \\
30^{\circ} 20^{\prime}\end{array}$ & 120 & 95 & 39 & 30.7 & 61 & $\begin{array}{c}88 \mathrm{P} \\
6 \mathrm{~S} \\
6 \mathrm{~B}\end{array}$ & $65-300$ & 17 & 31 \\
\hline 4 & $\begin{array}{c}64^{\circ} 33^{\prime}- \\
30^{\circ} 19^{\prime}\end{array}$ & 120 & 85 & 52 & 31.0 & 55 & $\begin{array}{c}90 \mathrm{P} \\
5 \mathrm{~S} \\
5 \mathrm{~B}\end{array}$ & $67-310$ & 14 & 26 \\
\hline
\end{tabular}

Table 1. Main characteristics of studied pine forest communities in the northernmost taiga of Republic of Karelia. Notes: tree stand composition (\% from basal area): $\mathrm{P}$ - pine, $\mathrm{S}$ - spruce, $\mathrm{B}-$ birch.

\section{Data processing and statistical analysis}

Data processing was done by one-way ANOVA using Excel (Ivanter et Korosov 2010). A preliminary analysis of the distribution of signs of lichen thalli (the width of the anatomical layers) revealed the absence of a normal distribution in individual compared samples. After transforming the values using logarithm, the distribution of the trait was obtained close to normal. The distribution of logarithms of anatomical indicators of lichen thalli was analyzed. 
Tables 2 and 3 show the mean values (M) of anatomical layers thickness in lichen thalli and the median (Me) logarithms of the layer thickness. Study of relationships between the parameters of the photosynthetic complex (the concentration of photosynthetic pigments) and the width of anatomical layers of $U$. hyperborea and

\section{Results}

\section{Structural features of thallus}

Anatomical studies have shown that all layers in the thalli of two lichen species studied vary within a wide range (Table 2,3 ). Coefficient of variance (CV) in $H$. physodes samples varied in the range of $19-37 \%$ in all the thalli collected, with the thickness of the algal layer being most variable $(\mathrm{CV}=37 \%)$ (Table 2). Comparing the two age groups, the large variability $(\mathrm{CV})$ in the thickness of the layers were apparent in young $H$.physodes thalli. Contrastingly, the upper cortex layer and thallus thickness in mature thalli were much more stable (CV below $30 \%$ ) with increasing variability of the algal layer thickness $(\mathrm{CV}=41 \%)$. The algal layer made up $30-40 \%$ of the thallus thickness. With an increase in thickness of the lichen thallus for this species, the proportion of algal layer to thallus thickness increased as well. No significant difference in photobiont layer thickness (one-way ANOVA) was found between young and mature thalli of $H$. physodes (Table 2). The proportion of the algal layer was slightly higher in mature thalli.

Within the samples of $U$. hyperborea the

\section{Content of photosynthetic pigments}

Analysis of photosynthetic pigments of two lichen species showed that $U$. hyperborea has a 2-fold higher values of photosynthetic pigments content, in particular chlorophyll $a$ and carotenoids, compared to
H. physodes was accomplished using correlation and regression analysis.

Level of a variation of parameters was estimated using coefficient of variance which is calculated as $\mathrm{CV}=\sigma / \mathrm{M}^{*} 100 \%$, where $\sigma-$ a standard deviation, $M-$ an arithmetic average (Ivanter et Korosov 2010).

thickness of individual layers also showed the high variation (CV from 26 to $49 \%$ ). The thickness of the upper cortex layer and medulla which are both formed by the fungal symbiont varied more than algal layer (Table 3). In two groups of thalli medulla thickness $(\mathrm{CV}=53 \%)$ and the upper cortex layer thickness $(\mathrm{CV}=40 \%)$ varied considerably in young thalli. The thickness of all anatomic structures stabilized in mature thalli (CV from 18 to $27 \%$ ) (Table 3), except for the thickness of the upper cortex layer, which showed an equally high level of variability in the three studied samples $(\mathrm{CV}=40 \%)$. Algal layer thickness was characterized by less variability in this species $(\mathrm{CV}=30 \%$ in young, $\mathrm{CV}=21 \%$ in mature). The proportion of algal layer in the thalli of $U$. hyperborea was $30-40 \%$ and did not show any relation with thallus thickness. According to the ANOVA results, comparison of the anatomical structures of young and mature thalli resulted in significant differences in thallus thickness, algal layer, medulla and lower cortex layer thicknesses (Table 3).

the thalli of $H$. physodes (Tables 4, 5).

According to one-way ANOVA, the difference between pigment contents in mature and young thalli of $H$. physodes was significant $(\mathrm{p}<0.01)$ (Table 4$)$. 


\begin{tabular}{|l|c|c|c|c|}
\hline $\begin{array}{c}\text { Thalli } \\
\text { groups }\end{array}$ & $\begin{array}{c}\text { TT }(\boldsymbol{\mu m}) \\
\mathbf{M} \pm \boldsymbol{\sigma}\end{array}$ & $\begin{array}{c}\mathbf{U C}(\boldsymbol{\mu m}) \\
\mathbf{M} \pm \boldsymbol{\sigma}\end{array}$ & $\begin{array}{c}\text { AL }(\boldsymbol{\mu m}) \\
\mathbf{M} \pm \boldsymbol{\sigma}\end{array}$ & $\begin{array}{c}\text { Propotion of algal } \\
\text { layer }(\mathbf{\%}) \mathbf{M} \pm \boldsymbol{\sigma}\end{array}$ \\
\hline H. physodes & $288.5 \pm 70.4$ & $45.1 \pm 8.2$ & $117.3 \pm 40.8$ & $43.1 \pm 9.4$ \\
\hline CV (\%) & 25 & 19 & 37 & 23 \\
\hline Young thalli & $221.97 \pm 90.4$ & $35.7 \pm 9.6$ & $77.2 \pm 30.4$ & $31.4 \pm 12.1$ \\
\hline CV (\%) & 41 & 28 & 39 & 36 \\
\hline Mature thalli & $202.71 \pm 54.3$ & $35.8 \pm 8.4$ & $68.5 \pm 28.2$ & $35.6 \pm 7.2$ \\
\hline CV (\%) & 27 & 22 & 41 & 21 \\
\hline $\mathrm{p}$ & 0.72 & 0.28 & 0.33 & $0.03 *$ \\
\hline
\end{tabular}

Table 2. Thickness of anatomical layers of thalli of Hypogymnia physodes.

Notes: TT - thallus thickness, UC - upper cortex, $\mathrm{AL}$ - algal layer, $\mu \mathrm{m}$ - micrometer; $\mathrm{M}-$ mean $(n=60), \sigma-\mathrm{a}$ standard deviation, $p-$ significance level $\left(^{*}-\mathrm{p}<0,05\right.$, $* *-\mathrm{p}<0,01, * * *-\mathrm{p}<0,001)$.

\begin{tabular}{|l|c|c|c|c|c|c|}
\hline $\begin{array}{c}\text { Thalli } \\
\text { groups }\end{array}$ & $\begin{array}{c}\mathbf{T T}(\boldsymbol{\mu m}) \\
\mathbf{M} \pm \boldsymbol{\sigma}\end{array}$ & $\begin{array}{c}\mathbf{U C}(\boldsymbol{\mu m}) \\
\mathbf{M} \pm \boldsymbol{\sigma}\end{array}$ & $\begin{array}{c}\mathbf{A L}(\boldsymbol{\mu m}) \\
\mathbf{M} \pm \boldsymbol{\sigma}\end{array}$ & $\begin{array}{c}\mathbf{M E D} \\
(\boldsymbol{\mu m}) \\
\mathbf{M} \pm \boldsymbol{\sigma}\end{array}$ & $\begin{array}{c}\mathbf{L C}(\boldsymbol{\mu m}) \\
\mathbf{M} \pm \boldsymbol{\sigma}\end{array}$ & $\begin{array}{c}\text { Part of } \\
\mathbf{a l g a l} \\
\text { layer }(\%) \\
\mathbf{M} \pm \boldsymbol{\sigma}\end{array}$ \\
\hline U.hyperborea & $151.1 \pm 43.7$ & $10.6 \pm 4.3$ & $49.7 \pm 13.8$ & $73.7 \pm 35.9$ & $17.0 \pm 4.4$ & $34.1 \pm 10.1$ \\
\hline CV (\%) & 29 & 40 & 28 & 49 & 26 & 30 \\
\hline Young thalli & $119.4 \pm 26.3$ & $10.4 \pm 4.2$ & $43.4 \pm 12.9$ & $49.5 \pm 26.4$ & $16.1 \pm 4.2$ & $37.5 \pm 13.2$ \\
\hline CV (\%) & 22 & 40 & 30 & 53 & 26 & 35 \\
\hline Mature thalli & $182.8 \pm 33.4$ & $10.8 \pm 4.4$ & $56.0 \pm 11.7$ & $97.9 \pm 26.7$ & $18.0 \pm 4.5$ & $30.8 \pm 4.6$ \\
\hline CV (\%) & 18 & 40 & 21 & 27 & 25 & 15 \\
\hline$p$ & $0.00^{* * *}$ & 0.6 & $0.00^{* * *}$ & $0.00^{* * *}$ & $0.02 *$ & 0.2 \\
\hline
\end{tabular}

Table 3. Thickness of anatomical layers of thalli of Umbilicaria hyperborea.

Notes: TT - thallus thickness, UC - upper cortex, AL - algal layer, MED - medullae, LC - lower cortex, $\mu \mathrm{m}-$ micrometer; $\mathrm{M}-$ mean $(n=60), \sigma-\mathrm{a}$ standard deviation, $p$ - significance level $(*-\mathrm{p}<0.05, * *-\mathrm{p}<0.01, * * *-\mathrm{p}<0.001)$.

There were significantly less photosynthetic pigments in young thalli than in mature ones, while the thickness of the algal layer in these groups did not differ (Table 3). Meanwhile, the $\mathrm{Chl} a / b$ ratio changed slightly (1.5-1.6) between age groups.

Significant differences between the amount of photosynthetic pigments in young and mature thalli were revealed for $U$. hyperborea (Table 5). The higher pigment amount was contained in young thalli than in mature ones. Moreover, the content of all photosynthetic pigments significantly varied in the samples of young thalli of $U$. hyperborea (CV from 31 to $70 \%$ ). In mature thalli, only the content of chlorophyll $a$ and carotenoids stabilized (CV 23\% and $19 \%$, respectively). The ratio of chlorophylls to carotenoids was stable (CV -22 $-23 \%$ in three samples) and varied within a narrow range (2.7-2.8). 
STRUCTURAL AND ECOPHYSIOLOGICAL FEATURES OF LICHENS

\begin{tabular}{|l|c|c|c|c|c|c|}
\hline \multirow{2}{*}{ Species } & \multicolumn{7}{|c|}{ Content of photosynthetic pigments (mg / g dry mass) } \\
\cline { 2 - 7 } & $\mathbf{C h l} \boldsymbol{a}$ & $\mathbf{C h l} \boldsymbol{b}$ & $\mathbf{C h l}(\boldsymbol{a}+\boldsymbol{b})$ & $\mathbf{C a r}$ & $\boldsymbol{a} / \boldsymbol{b}$ & $\boldsymbol{a}+\boldsymbol{b} / \mathbf{c a r}$ \\
\hline H. physodes & $0.06 \pm 0.01$ & $0.04 \pm 0.01$ & $0.11 \pm 0.02$ & $0.04 \pm 0.01$ & 1.6 & 2.9 \\
\hline CV (\%) & 24 & 36 & 26 & 32 & 18 & 50 \\
\hline Young thalli & $0.05 \pm 0.004$ & $0.03 \pm 0.01$ & $0.09 \pm 0.02$ & $0.03 \pm 0.01$ & 1.6 & 2.7 \\
\hline CV (\%) & 31 & 33 & 33 & 32 & 13 & 29 \\
\hline Mature thalli & $0.07 \pm 0.001$ & $0.05 \pm 0.01$ & $0.12 \pm 0.01$ & $0.05 \pm 0.01$ & 1.5 & 3.1 \\
\hline CV (\%) & 7 & 32 & 16 & 23 & 21 & 62 \\
\hline$p$ & $0.00^{* *}$ & $0.00^{* *}$ & $0.00^{* *}$ & $0.00^{* *}$ & - & - \\
\hline
\end{tabular}

Table 4. Content of photosynthetic pigments in thalli of Hypogymnia physodes. Notes: $* *$ - significance level $(\mathrm{p}<0.01)$.

\begin{tabular}{|l|c|c|c|c|c|c|}
\hline \multirow{2}{*}{ Species } & \multicolumn{6}{|c|}{ Content of photosynthetic pigments (mg / g dry mass) } \\
\cline { 2 - 7 } & $\mathbf{C h l} \boldsymbol{a}$ & $\mathbf{C h l} \boldsymbol{b}$ & $\mathbf{C h l}(\boldsymbol{a}+\boldsymbol{b})$ & $\mathbf{C a r}$ & $\boldsymbol{a} / \boldsymbol{b}$ & $\boldsymbol{a}+\boldsymbol{b} / \mathbf{c a r}$ \\
\hline U.hyperborea & $0.14 \pm 0.04$ & $0.04 \pm 0.03$ & $0.19 \pm 0.07$ & $0.07 \pm 0.02$ & 4.2 & 2.8 \\
\hline CV (\%) & 31 & 64 & 38 & 31 & 54 & 22 \\
\hline Young thalli & $0.16 \pm 0.05$ & $0.05 \pm 0.03$ & $0.21 \pm 0.07$ & $0.07 \pm 0.03$ & 3.6 & 2.8 \\
\hline CV (\%) & 32 & 54 & 36 & 36 & 49 & 22 \\
\hline Mature thalli & $0.12 \pm 0.03$ & $0.03 \pm 0.02$ & $0.15 \pm 0.05$ & $0.06 \pm 0.01$ & 5.1 & 2.7 \\
\hline CV (\%) & 23 & 70 & 32 & 19 & 51 & 23 \\
\hline$p$ & $0.02^{*}$ & $0.03^{*}$ & $0.02^{*}$ & $0.03^{*}$ & $0.02^{*}$ & 0.3 \\
\hline
\end{tabular}

Table 5. Content of photosynthetic pigments in thalli Umbilicaria hyperborea. Notes: * - significance level $(\mathrm{p}<0.05)$.

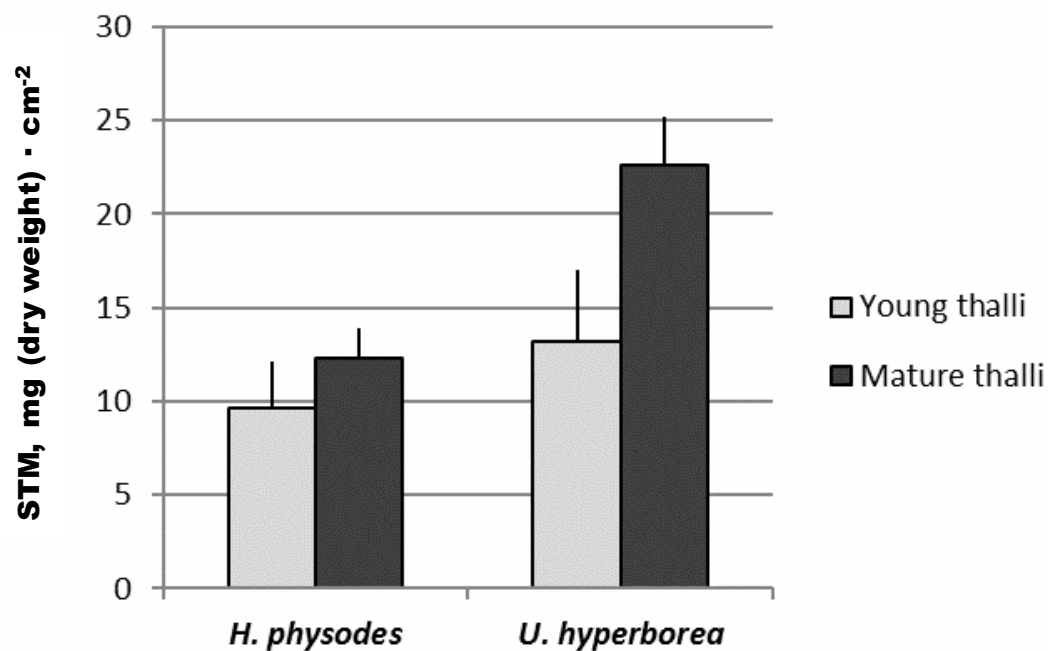

Fig. 1. Specific lichen thallus mass (STM) in young and mature thalli of Hypogymnia physodes and Umbilicaria hyperborea. 


\section{Specific thallus mass}

STM [mg (dry weight) $\left.\cdot \mathrm{cm}^{-2}\right]$ calculated for young and mature $H$. physodes thalli differed between young and mature thalli: $9.6 \pm 1.5$ and $12.3 \pm 2.1$, respectively $\left(\mathrm{p}=0.009^{* *}\right)$ (Fig. 1). The STM values for young and mature thalli of $U$. hyperborea

\section{Discussion}

Current study shows there are significant differences in the anatomical parameters and content of photosynthetic pigments in two species of lichens of different biomorphs and ecological groups. Such differences may be indicative of different ways of adaptation of the studied species to environmental conditions. It is known, that the variations in the thickness of the thallus layers of $H$. physodes with microclimate might be related to the alterations in pseudotissue formation which contributes to the adaptive ability of lichens (Hyvärinen 1992). Variations in the thickness of the thallus layers as well as in the content of photosynthetic pigments were found in samples of $H$. physodes (Table 2, 4). The thickness of the algal layer and the content of photosynthetic pigments increased from young to mature thalli of $H$. physodes. Obtained values of total content of photosynthetic pigments in thalli of $H$. physodes in northernmost boreal forests is much lower in comparison with the species samples from southern habitats (middle and southern boreal subzone). For southern boreal forests the following values of pigments were reported ( $\mathrm{mg} \cdot \mathrm{g}^{-1}$ dry mass): chl $a-0,483$, chl $b-0,229$ (Khramchenkova 2017), chl $a-0,421, \operatorname{chl} b-1.042$ (Androsova et al. 2008).

Obtained values of high chlorophyll $b$ content, as evidenced by the chlorophyll $a / b$ ratio, which is $1.5-1.6$, are notable features of the photosynthetic apparatus of $H$. physodes. Such increase in the proportion of chlorophyll $b$ in photosystems may were significantly different $\left(\mathrm{p}=0.007^{* *}\right)$ : $13.2 \pm 2.8$ - for young and $22.6 \pm 1.6$ for mature thalli. Thus, values of STM in mature thalli of $U$. hyperborea were almost 2-fold higher than in thalli of $H$. physodes.

indicate its photoprotective role. It was demonstrated for different photosynthetic objects that with increasing insolation the amount of chlorophyll $b$ increases in the chlorophylliferous tissues of the plant as well as its relative amount in the sum of chlorophylls (Rosevear et al. 2001). The participation of chlorophyll $b$ in the rearrangements of the antenna complexes of photosystems is well known (Eggink et al. 2001), and it was shown that the level of biosynthesis of the main proteins of the photosynthetic antenna depends on the level of biosynthesis of chlorophyll $b$ (Tanaka et Tanaka 2000).

The upper cortex of $H$. physodes has ash-gray color without dark pigments, such as melanin, which performs a solar radiation screening function (Färber et al. 2014). It is not established whether the photobiont cells are screened by the presence of colorless secondary substances (atranorin) in the upper cortex layer (Solhaug et al. 2009). Perhaps the photobiont in this case, showing a high plasticity (variability of the thickness of the algal layer and variation in the content of pigments), realizes its contribution to the adaptation of the complex organism to the environmental condition, which is reported in some studies for different lichen species (Sadowsky et Ott 2016, Sonina et al. 2017).

Distinguished data on anatomy and physiology were obtained for $U$. hyperborea species. It was found that the thickness of the thallus increases mainly due to increase in the fungal layers (medulla, lower 
cortex) and also algal layer from young to mature thalli (Table 3). Medulla thickness in the young thalli as well as the upper cortex in young and mature thalli were more variable, while the algal layer showed a lower range of variation. This demonstrated the significant role of the mycobiont in adaptation of thallus thickness to external environmental conditions. The obtained data are consistent with the literature on the important role of the mycobiont in lichen adaptation (Färber et al. 2014). Interestingly, the proportion of chlorophyll $b$ in chlorophyll $a / b$ ratio (4-5) were significantly lower compared to H. physodes (Table 4, 5). This data are consistent with results of anatomical study. In this case, photosynthetic pigments (chlorophylls and carotenoids) perform lightharvesting function, while the protective role is assumed to be performed by the mycobiont. This is revealed in the structure, by varying the anatomical layer of mycobiont, and also its functional features (the presence of dark pigments - melanin) (Bagmanyan et al. 2014).

The young and mature thalli of $H$. physodes and $U$. hyperborea have different morphological characteristics and belong to different ontogenetic states. A comparison anatomical structure and the content of photosynthetic pigments between these age group of two studied species established differences. For thalli of $H$. physodes the differences between the anatomical layers in lichen thallus were not significant, while the content of photosynthetic pigments was significantly different (contribution of the algal layer to functioning of symbiotic organism). The thickness of the layers did not differ in the age groups (Table 2) while the thickness of the algal layer varied considerably $(\mathrm{CV}>30 \%)$. Significantly more photosynthetic pigments were found in mature thalli (Table 4). These data emphasize the stability of the anatomical layers formed by the mycobiont, and also indicate the great plasticity of the algal symbiont, both structural and physiological.

For $U$. hyperborea species, the thickness of the thallus and anatomical layers increased from young to mature thalli (Table 3) and the content of photosynthetic pigments significantly decreased in this direct (Table 5), while the thickness of the algal layer varied slightly $(\mathrm{CV}<30 \%)$. The change in the thickness of the mycobiont layers can cause changes in the production of lichens secondary metabolites (tridepsides - gyrophoric, umbilicaric and dipsides - lecanoric acids) (Posner et al. 1992) which related to decline of algal biont growth in lichen thallus. Hager et al. (2008) found out the inhibition of the growth of algal cells of Trebouxia jamesii by barbatic acids in thallus of Heterodea muelleri (Hampe) Nyl. This property of secondary lichen acids might be one of the possible explanations of the decrease of photosynthetic pigments content in thalli $U$. hyperborea in current study.

Comparative analysis of the two studied species showed that thickness of the upper cortex layer differs significantly in $H$. physodes and $U$. hyperborea, there are it almost 4 times thinner in Umbilicaria samples (Table 2, 4). The lower thickness of the upper cortex layer in dark-colored $U$. hyperborea due to presence of brown cortical pigment melanin provides a better thermal regime and protection for the algal layer (Byazrov 2002, Atala et al. 2015). Thus, adaptogenic role of the mycobiont in the symbiotic organism may affect both structural (varying of layers) and functional (content of melanin) characteristics.

Specific thallus mass (STM, biomass per unit area) is an important functional indicator. In fact, lichens can improve their water economy by increasing their specific thallus mass, especially by thickening the photobiont layer (Gauslaa et Coxson 2011). Lichens of Umbilicaria genus prefer open habitats (Purvis et al. 1992), belong to heliophytes. Higher values of STM, especial- 
ly for mature thalli can provide higher water holding capacity. $H$. physodes species is related to wet and shaded habitats and characterized by rather high sensitivity to changes in humidity conditions (Hyvärinen 1992, Androsova et al. 2009). Obtained data on STM for this species are significantly lower than for $U$. hyperborea, which suggests its ecophysiological significance in lower water holding capacity in H. physodes.

Despite the fact that the photobiont in two species are closely related taxa (unicellular green algae of the genus Trebouxia) a high variability of photosynthetic pigments content in $H$. physodes thalli has been revealed, whereas in U. hyperborea, the mycobiotic layers showed high structural variability. It can be concluded that both mycobiont and photobiont contribute to their adaptation to environmental factors. In the present study it was obtained that the proportion of variation in anatomical structures and the content of photosynthetic pigments probably less depends on taxonomic position of photobiont and more determined by the plasticity of the individual components of the symbiotrophic organism.

\section{References}

Androsova, V. I., Verzhbitskaya, E. V. and Slobodyanik, I.I. (2008): The content of photosynthetic pigments in the thallus of lichen Hypogymnia physodes L. in different habitat conditions. Proceedings of the Russian Conference "Fundamental and Applied Problems of Botany at the Beginning of the 21st Century" at the XII Congress of the Russian Botanical Society. (Petrozavodsk, September, 22-27, 2008). Petrozavodsk: KarRC RAS. Vol. 6, pp. 1012. (In Russian).

Androsova, V. I., Tarasova, V. N. and Gorshkov, V. V. (2009): Ecology of the species Hypogymnia physodes (L.) Nyl. in the coniferous forests of southern Karelia. Materials of the V International Conference. "Study offungi in biogeocenoses. Perm, pp. 268-272. (In Russian).

Atala, C., Schneider, C., Bravo, G., Quilodrán, M. and Vargas, R. (2015): Anatomical, physiological and chemical differences between populations of Pseudocyphellaria. Gayana Botánica, 72(1): 21-26.

Bagmanyan, I. A., Myamin, B. E., Giginyak, Yu. G., Borodin,O. I. and Kurchenko, V. P. (2014): Possible role of melanin in adaptation of lichens to extreme factors of Antarctic. Proceeding of the Belarusian State University, 9(2): 82-89.

ByAzROV, L. G. (2002): Lichens in ecological monitoring. Moscow, 336 p. (In Russian).

DAvydov, E.A. (2004): Additions to the lichen biota of Altai Mountains (Siberia). I. Turczaninowia, 7(4): 47-59. (In Russian).

DAvydov, E.A., Zhurbenko, M.P. (2008): Contribution to Umbilicariaceae (lichenized Ascomycota) studies in Russia I. Mainly Arctic species. Herzogia, 21: 157-166.

De VerA, J.P. (2012): Lichens as survivors in space and on Mars. Fungal Ecology, 5: 472-479.

DorshaKOVA, N.V. (2004): The quality of the environment of the Republic of Karelia and the morbidity of the population by bronchopulmonary pathology. Fundamental researches, 6: 8081. (In Russian)

Eggink, L. L., PARK, H. and Hoober, J. K. (2001): The role of chlorophyll b in photosynthesis: Hypothesis. BMC Plant Biol, 1: 2.

Färber L., Solhaug K., Esseen P., Bilger W. and Gauslaa Y. (2014): Sunscreening fungal pigments influence the vertical gradient of pendulous lichens in boreal forest canopies. Ecology, 95 (6): 1464-1471.

GADD, G. M. (2011): Geomycology. In: J. Reitner, V. Thiel (eds.): Encyclopedia of Geobiology. Part 7. Heidelberg: Springer, pp. 416-432. 
Gielwanowska, I., Olech, M. (2012): New ultrastructural and physiological features of the thallus in Antarctic lichens. Acta Biologica Cracoviensia Series Botanica, 54(1): 40-52.

GauslaA, Y., Coxson, D. (2011): Interspecific and intraspecific variations in water storage in epiphytic old forest foliose lichens. Botany, 89: 787-798.

GromtSEV, A.N. (2009): Forests of the Kostomukshsky Nature Reserve: structure, dynamics, and landscape features. Trans. of KarRC of RAS, 2: 71-78. (In Russian).

Hager, A., Brunauer, G., TÜrk, R. and Stocker-Wörgötter, E. (2008): Production and bioactivity of common lichen metabolites as exemplified by Heterodea muelleri (Hampe) Nyl. Journal of Chemical Ecology, 34: 113-120. DOI 10.1007/s10886-007-9408-9

Hauck, M., Helms, G. and Friedl, T. (2007): Photobiont selectivity in the epiphytic lichens Hypogymnia physodes and Lecanora conizaeoides. Lichenologist, 39(2): 195-204.

HYVÄrINEN, M. (1992): Adaptivity of the thallus structure of Hypogymnia physodes to microclimatic conditions. Lichenologist, 24(3): 267-279.

Ivanter, E. V., Korosov, A. V. (2010): Elementary biometrics. Petrozavodsk: Petrozavodsk State University, 104 p. (In Russian).

JARMishKo, V.T., LJANGUZOVA, I. V. (eds) (2002): Methods of studying of forest communities. Saint-Petersburg, 240 p. (In Russian).

Jones T. C., Hogg I. D., Wilkins R. J. and Green T. G. A. (2013): Photobiont selectivity for lichens and evidence for a possible glacial refugium in the Ross Sea Region, Antarctica. Polar Biology, 36: 767-774.

KHRAMCHENKOVA, O. (2017): Epiphytic lichens: humidity of thalli and concentration of assimilating pigments. Bulletin of science and practice, 3(16): 68-77. (In Russian).

LichtenthaleR, K., WelBuRn, A.R. (1983): Determination of total carotenoids and chlorophylls a and b of leaf extracts in different solvents. Biochemical Society Transactions, 11: 591-592. http://dx.doi.org/10.1042/bst0110591

Maslova, T. G., Popova, I. A. (1993): Adaptive properties of the plant pigment systems. Photosynthetica, 29: 195-203. (In Russian).

Meeben, J.F.J., Sanchez, A., Sadowsky, R., De La Torre, Ott, S. and De Vera, J.P. (2013): Extremotolerance and resistance of lichens: comparative studies on five species used in astrobiological research II. Secondary lichen compounds. Origins of Life and Evolution of Biospheres, 43(6): 501-526.

NASH, T. H. III (ed.) 2008: Lichen Biology. Second Edition, 486 p.

Posner, B., Feige, G.B. and Huneck, S. (1992): Studies on the chemistry of the lichen genus Umbilicaria Hoffm. Deutschland Z. Naturforsch, $47 \mathrm{p}$.

Purvis, O.W., Coppins, B.J., Hawksworth, D. L., James, P.W. and Moore, D.M. (1992): The Lichen flora of Great Britain and Ireland. London: Natural History Museum Publications in association with the British Lichen Society, $710 \mathrm{p}$.

Rosevear, M., Young, A. and Johnson, G. (2001): Growth conditions are more important than species origin in determining leaf pigment content of British plant species. Functional Ecology, 15: 474-480. DOI:10.1046/j.0269-8463.2001.00540.x

SADOWSKY, A., OTT, S. (2016): Symbiosis as a successful strategy in continental Antarctica: performance and protection of Trebouxia photosystem II in relation to lichen pigmentation. Polar Biology, 39: 139-151. https://doi.org/10.1007/s00300-015-1677-0.

Sapozhnikov, D. I., Maslova, T. G., Poppova, O. F., Popova, I. A. and Koroljova, O.Ya. (1978): Method of fixation and storage of the leaves for quantitative determination of plastid pigmets. Botanical Journal, 63: 1586-1592. (In Russian).

Solhaug, K. A., Lind, M., Nybakken, L. and GauslaA, Y. (2009): Possible functional roles of cortical depsides and medullary depsidones in the foliose lichen Hypogymnia physodes. Flora, 204: 40-48.

SoninA, A. V., TsunskAYA, A. A. (2016): Structural and functional adaptation of epilithic lichens of Umbilicaria genus in the White Sea coastal conditions. Czech Polar Reports, 6(2): 169179. DOI: $10.5817 /$ CPR2016-2-15. 
A. V. SONINA et al.

Sonina, A. V., Rumjantseva, A. D., Tsunskaya, A. A. and Androsova, V.I. (2017): Adaptations of epilithic lichens to the microclimate conditions of the White Sea coast, Czech Polar Reports, 7(2): 133-143. DOI: 10.5817/CPR2017-2-13

TANAKA, R., TANAKA, A. (2000): Chlorophyll $b$ is not just an accessory pigment but a regulator of the photosynthetic antenna. Porphyrins, 9(1): 240-245.

Usmanov, I.Yu., RAKHMANCUlOVA, Z. F. and Kulagina, A.YU. (2001): Ecological physiology of plants. Moscow: Logos, 2001, 224 p. (In Russian).

Wirth, V., Hauck, M. and Schultz, M. (2013): Die Flechten Deutschlands. Ulmer. 2. Stuttgart, $1244 \mathrm{p}$.

\section{Web sources / Other sources}

[1] Matveeva N. V. (ed) (2015): Plants and fungi of the polar deserts in the northern hemisphere. MARAFON, Saint-Petersburg, 320 p. (In Russian).

[2] Atlas of the Karelian ASSR (1989). Moscow: GUGK, 40 p. (In Russian). 